Research article

\title{
Removal of heavy metals from textile industry wastewater
}

\author{
Recep Turksoy ${ }^{1}$ (D), Gokhan Terzioglu² ${ }^{(D)}$, Ibrahim Ertugrul Yalcin $^{3}$ (D), \\ Ozlem Turksoy Terzioglu* ${ }^{*}$ (D), Goksel Demir ${ }^{5}$ (D)
}

${ }^{1}$ Independent researcher, 34250, Gaziosmanpasa, Istanbul, Turkey

${ }^{2}$ Independent researcher, 34676, Uskudar, Istanbul, Turkey

${ }^{3}$ Bahcesehir University, Faculty of Engineering \& Natural Sciences, Department of Civil Engineering, 34353, Besiktas, Istanbul, Turkey

${ }^{4}$ University of Health Sciences Turkey, Hamidiye Institute of Health Sciences, Department of Molecular Biology and Genetics, 34668, Uskudar, Istanbul, Turkey

${ }^{5}$ University of Health Sciences Turkey, Hamidiye Faculty of Health Sciences, Department of Occupational Health and Safety, 34668, Uskudar, Istanbul, Turkey

\begin{abstract}
Wastewaters of several industries such as textile, leather or dye etc., contain dangerous and toxic compounds, even some of which are potential carcinogenics. Considering the volume and composition, wastewaters of the textile industry have much more polluting characteristics compared to other industries. Although treatment processes must definitely be implemented in point of environment and living organisms, many factories discharge their wastewaters to acceptor media without any treatment because of high costs. This study investigated zeolite and clay with high availability and low cost in wastewater treatment as more economically feasible alternatives to activated carbon. The wastewater treatment adequacy of zeolite-clay mixture was also investigated. We determined the optimum treatment time for heavy metal removal from the dye-containing wastewater samples as 6 hours. The mixture of clay+zeolite+activated carbon provided the highest removal of $\mathrm{Cd}, \mathrm{Cu}, \mathrm{Mn}, \mathrm{Pb}$, and $\mathrm{Zn}$ compared to zeolite, clay, activated carbon, activated carbon+clay, activated carbon+zeolite and clay+zeolite.
\end{abstract}

Keywords: Activated carbon; clay; heavy metal removal; textile dyes; wastewater treatment; zeolite

\section{Introduction}

Both the growing world population and the changing sense of lifestyle and fashion boost the demand for textile products (Uzal et al., 2005; Mercimek, 2007). The textile industry is considered as the most polluting industry due to the enormous diversity of chemicals used in the production processes. More than 100,000 dyes and 2000 types of chemicals are used in the industry and the annual production of textile dyes is around 500,000 tons (Kapdan and Kargi, 2000; Halimoon and Yin, 2010; Arora, 2014). The wastes resulting from the dyeing of products such as yarn and fabric has the biggest share in the pollution related to textile wastewaters (Mercimek, 2007). Even very small amounts of dye residues in the wastewaters of the textile industry can cause significant pollution (Sener, 2008).

The colorant wastes colorize the water and thus prevent the sunlight to reach the depths of water bodies and threaten the livestock that lives in the affected rivers, lakes and seas. The oxygen levels also decrease in affected aquatic ecosystems due to decreasing photosynthetic activity as a result of blocking the penetration of sunlight by colorants (Banat et al., 1996; Mercimek, 2007). The other most important hazardous

* Corresponding author.

E-mail address: ozlem.turksoy@ @bu.edu.tr (O. Turksoy Terzioglu).

https://doi.org/10.51753/flsrt.958165 Author contributions

Received 28 June 2021; Accepted 8 August 2021

Available online 30 August 2021

2718-062X ( 2021 This is an open access article published by Dergipark under the CC BY license. 
constituents in these wastewaters, that have ecologically negative impacts on aquatic ecosystems and also have deteriorative effects on human health, are heavy metals.

\subsection{Numerous heavy metals are used in textile industry}

Heavy metals can be found in textiles naturally, or as a result of production and dyeing processes; protective agents used during storage may also lead to penetration of heavy metals into textile fibers. Colour pigments in textile dyes are produced using heavy metals such as chromium $(\mathrm{Cr})$, nickel $(\mathrm{Ni})$, zinc $(\mathrm{Zn})$, lead $(\mathrm{Pb})$, copper $(\mathrm{Cu})$ and cadmium $(\mathrm{Cd})$ (Bhardwaj et al., 2014).

\subsection{Heavy metals have numerous negative effects on environment and human health}

Heavy metals are commonly defined according to their density; metals with a density higher than $5 \mathrm{~g} / \mathrm{cm}^{3}$ are classified as heavy metals ( $\mathrm{Gu}$ and Lin, 2010; Yalcin et al., 2020). Although heavy metals exist in nature, they are very toxic, especially in high concentrations and can accumulate in the soil, water, and human body (Mathur et al., 2005; Suresh et al., 2015; Ozyigit et al., 2018). Even trace amounts of some heavy metals are a risk for the health of humans and other organisms and cannot be destroyed or degraded by living things. Drinking polluted water, ingesting heavy metal-containing foods via the food chain, or inhaling air containing higher concentrations of heavy metals near sources of emission may lead to heavy metal toxicity (Karnib et al., 2014; Yilmaz et al., 2021).

Cadmium $(\mathrm{Cd})$ is naturally in the environment, but it is also hazardous due to bioaccumulation. $\mathrm{Cd}$ is a poisonous substance and even cause cancer and premature death; long-term exposure to $\mathrm{Cd}$ leads to systemic toxicity in reproductive, skeletal, cardiovascular, urinary, respiratory, and nervous systems (Rahimzadeh et al., 2017; Hocaoglu-Ozyigit and Genc, 2020). Plants can take this metal from the environment and thus its concentration increases along the food chain (Jaishankar et al., 2014; Dogan et al., 2016).

Lead $(\mathrm{Pb})$ is not only unnecessary for human life but also causes health problems as a toxic heavy metal and especially affects pregnant women, children, and elderly persons. It harms our endocrine, nervous, circulatory, skeletal, and immune systems and can also cause mental retardation in children. It is also very harmful to plants, leads to chlorophyll damage by fastening and related growth retardation (Jaishankar et al., 2014; Ozyigit et al., 2016).

Zinc $(\mathrm{Zn})$ is another heavy metal and it is required for the proper function of the human body, unlike $\mathrm{Cd}$ and $\mathrm{Pb}$. Although $\mathrm{Zn}$ is an essential element for our bodies, long-term exposure to the excess amount of $\mathrm{Zn}$ causes infertility and diminishes immune function, and cholesterol balance (Yasar and Ozyigit, 2009; Zhang et al., 2012). Cd, Pb, and $\mathrm{Zn}$ also accumulate in crops and vegetables in fields near polluted areas (Zhang et al., 2012).

Nickel (Ni) is omnipresent, but its function for animal life has not been clearly understood yet. Exposure to Ni can cause lung fibrosis, allergy, kidney diseases, cardiovascular diseases and also lead to cancer and epigenetic changes (Genchi et al., 2020).

Copper $(\mathrm{Cu})$ is another toxic heavy metal, and exposure to excess amounts of $\mathrm{Cu}$ causes Wilson's Disease, mucosal irritation, gastrointestinal disorders, toxic effects on the kidneys and liver, and capillary damages (Shrivastava, 2009).

Aluminum ( $\mathrm{Al})$ is also a ubiquitous metal, naturally founds in soil and constitutes $8 \%$ of the earth's surface, but it is also toxic. The toxicity level of $\mathrm{Al}$ is determined by several factors such as organic content and pH (Dogan et al., 2014; Jaishankar et al., 2014). In acidic soil, it can decrease crop by inhibiting root growth and changing the cellular structure of leaves (Ozyigit et al., 2019). It also negatively affects aquatic organisms such as fishes, seaweeds, and crawfishes in high concentrations (Jaishankar et al., 2014). The toxic effects of Al on human bone marrow, skeletal muscles, heart, liver, and brain are also well defined (Nayak, 2002).

\subsection{Adsorbent compounds can be used in wastewater treatment}

Wastewater treatment methods differ according to target pollutants (Talarposhti et al., 2001; Mercimek, 2007). Due to the wide variety of chemicals used in the washing, bleaching, and dyeing processes of the fibers used in the textile industry, the compositions of wastewaters vary. As a result, wastewater treatment is a very complicated activity (Pagga and Brown, 1986; Donlon et al., 1997). Classical methods such as coagulation and flocculation are not successful in the removal of the wastes of the dyeing processes. Thus, several methods have been developed for the treatment of the wastewaters of the dye industry, such as adsorption to organic and inorganic matrices, photocatalysis, enzymatic or microbiological separation, chemical oxidation, etc. (Santos and Boaventura, 2008).

The adsorption process via solid adsorbents is considered as one of the most useful methods for the removal and treatment of inorganic and organic pollutants in the he wastewaters of the dye industry. This method has a simple design and ease of use because of its low initial cost and land needs. Researchers recently pay special attention to finding low-cost adsorbents with high pollutant-binding capacity (Rashed, 2013).

\subsubsection{Activated Carbon}

Adsorption is an important process in the removal of colorants from wastewater. The most commonly used adsorbent is activated carbon because of its high adsorption capacity. Activated carbon consists of $87-97 \%$ carbon, and the rest of it may contain hydrogen, oxygen, sulphur, and nitrogen (Tchobanoglous et al., 1991).

Although activated carbon is an efficient adsorbent for numerous organic and inorganic compounds due to its high porosity, high surface reaction affinity and large surface area, the cost is very high (Jaroniec and Choma, 1986; Bolisetty et al., 2019). So researchers have directed their attention to various alternatives, such as agricultural by products, industrial wastes, and natural materials (Sener, 2008).

\subsubsection{Zeolite}

Zeolites are very cheap, effective adsorbents to adsorb heavy metals from wastewater samples due to their ion exchange capability (Babel and Kurniawan, 2003). Zeolites are hydrated aluminosilicate minerals, and their structure is an anionic tetrahedron of $\mathrm{AlO}_{4}$ and $\mathrm{SiO}_{4}$ (Pohl, 2011). They consist of millions of micropores like honeycomb and cage which are 2-10 microns in size and contain varying cations; because cations are bound by weak bonds, zeolites can easily change their ions. 
Zeolites are used in various applications, such as ion-exchange, removal of solvents and gas, petrochemical cracking, adsorption, etc., due to their porous structure. Hazardous wastes can be converted into environmentally safe products using zeolites (Shevade and Ford, 2004). There are more than 40 types of zeolites in nature and eight types of them are important in global markets. Clinoptilolite is the most abundant zeolite in nature (Babel and Kurniawan, 2003) and an important type of natural zeolites in Turkey due to its high reserve, formation, homogeneity, and high mineral quality. Although natural types of zeolites exist, they do not have the desired purity and pore diameters, and thus artificial zeolite has extensive usage (Gulen et al., 2012). Synthetic zeolites such as NaPl have markedly bettered ion-exchange ability compared to natural ones such as clinoptilolite. $\mathrm{pH}$ is an important determinant to affect ionexchange adsorption and low $\mathrm{pH}$ values decrease adsorption capacity as a result of hydrogen ion competition (Bolisetty et al., 2019).

\subsubsection{Clay}

Clay is a fine-grained natural soil or rock material and contains one or more clay minerals with traces of organic matter and metal oxides. The composition of clay consists of silica, alumina, water, and also iron, alkalis, or soil alkalis. Some of the minerals such as quartz, calcite, feldspar, and pyrite can be found in some clays, so the composition of all clays is not the same (Toprakezer, 2009).

When clay comes in contact with water, it softens, expands, and gains a plastic structure. Clay is a preferred material in the industry, because of its absorption and adsorption capabilities, small grain size, large surface area, and high plasticity (Isci, 2002; Toprakezer, 2009). It has been shown that the surfaces of clay minerals are negatively charged while their edges and corners are positively charged. This character allows cations and anions in the solution to adhere to the surface and provides adsorptive and absorptive properties (Demir, 2008).

Three essential species of clay are smectites, kaolinite, and micas. Clay is a cheap and plenteous material, and montmorillonite is a smectite, has the highest cation exchange capacity, and 20 times cheaper than active carbon (Babel and Kurniawan, 2003). As they have a great adsorption capacity, they have been utilized for the removal of toxic heavy metals from aqueous solutions for years. Both natural and modified clay forms can effectively remove diverse heavy metals from polluted water samples (Uddin, 2017). Although the heavy metal removal efficacy of clays is lower than zeolites, their high availability and low-cost make them preferable (Babel and Kurniawan, 2003). The environmental risks grow day by day but the most effective method for the removal of heavy metals could not be found yet. In this study, we aimed to find out a substance for developing a more effective and relatively low-cost removal of heavy metals from the wastewaters of dye plants. We investigated the effectiveness of zeolite and clay in wastewater treatment as more abundant and more economical alternatives to widely used activated carbon, the use of zeolite and clay. The effectiveness of zeolite, clay and activated carbon separately and together in wastewater treatment were also analyzed.

\section{Materials and methods}

$0.100 \mathrm{~g}$ of Yellow PG (Scientific Name: Direct Yellow 142) (D1), Red BWS (Direct Red 243) (D2), Blue 4BL (Direct
Blue 200) (D3), Rose FR (Direct Red 227) (D4) and WSF 800 1.0 (D5) dyes were separately mixed with $10 \mathrm{ml}$ of purified water, and each of them completed to $1000 \mathrm{ml} .5 \mathrm{~g}$ of cotton fabric rags were soaked up with $75 \mathrm{ml}$ of the prepared dye samples and then heated.

When the temperature reached $100^{\circ} \mathrm{C}, 1 \mathrm{~g} \mathrm{NaCl}$ was added to each sample, and then each sample was boiled for 30 minutes. Thus, the salt acts on the covalent bonds to ensure stable dispersion of the dye into the fabric. After the water had been completely evaporated, it rinsed with $100 \mathrm{ml}$ cold ultra-pure water, and then the fabric was allowed to dry. The rinse water obtained in the same way as the wastewater of the factory. The acid-base values of the prepared dye samples measured by using the $\mathrm{pH}$ meter (Hanna-HI 2211).

35 samples were divided into 7 different groups for each dye. Active carbon, natural zeolite, and clay were applied to each sample separately and/or applied after being mixed with another for removing heavy metals. A total of $1 \mathrm{~g}$ of each remover or remover mix applied to every $10 \mathrm{ml}$ of each sample. The removers were held for 2,4 , and 8 hours, then filtered with the Whatman filter papers. $500 \mu \mathrm{L}$ of each filtered sample was placed on the Teflon cells, $5 \mathrm{ml}$ of $\mathrm{HNO}_{3}$ (Merck) was added on them, and then they were put in the microwave oven (Berghof MWS2).

The incubation times and temperatures in the microwave oven were 5 minutes at $145^{\circ} \mathrm{C}, 5$ minutes at $165{ }^{\circ} \mathrm{C}$ and 20 minutes at $175^{\circ} \mathrm{C}$, respectively; the incineration conducted in this way. After the procedure finished, the Teflon cells were allowed to cool for 20 minutes in the water bath. The lids of the cells carefully opened in the laminar flow, they were filtered using Whatman filters in $50 \mathrm{ml}$ conical centrifuge tubes, then completed to $50 \mathrm{ml}$.

The element analyses ( $\mathrm{Al}, \mathrm{Cd}, \mathrm{Cu}, \mathrm{Ni}, \mathrm{Pb}$, and $\mathrm{Zn}$ ) of the fully dissolved samples were conducted in the ICP-OES (Inductively Coupled Plasma Optical Emission Spectroscopy) (Perkin Elmer-Optima 7000 DV) in the range obtained by using the standards prepared using the multi-element stock solution (Merck $1000 \mathrm{ppm}$ ). Al was analyzed due to its existence in zeolite and the increase in $\mathrm{Al}$ concentration when zeolite mixed with the liquid. For statistical analysis, One Way ANOVA with Tukey's HSD Test was used, and $p<0.05$ was considered as statistically significant.

\section{Results and discussion}

\subsection{The samples had acceptable $p H$ values in terms of reusability}

The $\mathrm{pH}$ values of the textile dyes were given in Table 1 . When the values examined, the lowest $\mathrm{pH}$ value was determined as 7.16 for Direct Blue 200, while the highest $\mathrm{pH}$ value was determined as 9.88 for Direct Red 243. These values are not acidic, and therefore the remaining water samples of these most commonly used textile dyes can be reused after the wastewater treatment.

\begin{tabular}{ll}
\hline Dye & pH \\
\hline Yellow PG (Direct Yellow 142) & 9.57 \\
Red BWS (Direct Red 243) & 9.88 \\
Blue 4BL (Direct Blue 200) & 7.16 \\
Rose FR (Direct Red 227) & 7.25 \\
WSF 800 1.0 & 7.29 \\
\hline
\end{tabular}

Table 1

$\mathrm{pH}$ values for colorants.

*Those in parentheses are the scientific names. 
Table 2

Temporal changes in the heavy metal contents of the samples after the treatment with adsorbents $(\mathrm{Al}, \mathrm{Cd}$ and $\mathrm{Cu})$.

\begin{tabular}{|c|c|c|c|c|}
\hline \multicolumn{5}{|c|}{ Aluminum Concentration $\left(\mathrm{mg} \mathrm{L}^{-1}\right)($ mean $\pm \mathrm{SD})(0$ th Hour $32.88 \pm 5.99)$} \\
\hline Time/Treatment & 2th Hour & 4th Hour & 6th Hour & 8th Hour \\
\hline Carbon & $3.31 \pm 1.38$ & $2.97 \pm 1.42$ & $* 2.70 \pm 1.40$ & $2.92 \pm 1.42$ \\
\hline Zeolite & $294 \pm 59.46$ & $283.29 \pm 59.26$ & $273.30 \pm 56.70$ & $281.65 \pm 54$ \\
\hline Clay & $15.14 \pm 5.14$ & $13.64 \pm 5.30$ & $12.23 \pm 4.47$ & $13.43 \pm 4.60$ \\
\hline Carbon+Clay & $11.35 \pm 4.68$ & $9.91 \pm 4.30$ & $8.97 \pm 3.90$ & $9.40 \pm 4.09$ \\
\hline Carbon+Zeolite & $237.92 \pm 56.95$ & $225.88 \pm 53.03$ & $216.47 \pm 48.99$ & $224.40 \pm 49.48$ \\
\hline Clay+Zeolite & $254.45 \pm 59.48$ & $243.87 \pm 57.16$ & $232.60 \pm 59.52$ & $240.71 \pm 58.16$ \\
\hline Carbon+Clay+Zeolite & $180.85 \pm 71.28$ & $172.17 \pm 70.79$ & $165.58 \pm 68.53$ & $171.34 \pm 69.22$ \\
\hline \multicolumn{5}{|c|}{ Cadmium Concentration $\left(\mathrm{mg} \mathrm{L}^{-1}\right)($ mean \pm SD $)($ th Hour $9.00 \pm 3.91)$} \\
\hline Time/Treatment & 2th Hour & 4th Hour & 6th Hour & 8th Hour \\
\hline Carbon & $0.77 \pm 0.35$ & $0.70 \pm 0.35$ & $0.66 \pm 0.35$ & $0.68 \pm 0.35$ \\
\hline Zeolite & $0.90 \pm 0.37$ & $0.80 \pm 0.36$ & $0.73 \pm 0.35$ & $0.76 \pm 0.35$ \\
\hline Clay & $5.03 \pm 2.37$ & $4.64 \pm 2.00$ & $4.25 \pm 1.76$ & $4.45 \pm 1.86$ \\
\hline Carbon+Clay & $1.83 \pm 0.81$ & $1.60 \pm 0.81$ & $1.42 \pm 0.68$ & $1.48 \pm 0.72$ \\
\hline Carbon+Zeolite & $0.82 \pm 0.33$ & $0.72 \pm 0.32$ & $0.65 \pm 0.33$ & $0.70 \pm 0.33$ \\
\hline Clay+Zeolite & $2.90 \pm 1.63$ & $2.67 \pm 1.42$ & $2.53 \pm 1.30$ & $2.59 \pm 1.35$ \\
\hline Carbon+Clay+Zeolite & $0.64 \pm 0.34$ & $0.56 \pm 0.29$ & $* 0.50 \pm 0.28$ & $0.55 \pm 0.29$ \\
\hline \multicolumn{5}{|c|}{ Copper Concentration $\left(\mathrm{mg} \mathrm{L}^{-1}\right)(\mathrm{mean} \pm \mathrm{SD})(0$ th Hour 643.74 \pm 27.24$)$} \\
\hline Time/Treatment & 2th Hour & 4th Hour & 6th Hour & 8th Hour \\
\hline Carbon & $17.69 \pm 9.83$ & $16.51 \pm 9.15$ & $15.05 \pm 8.13$ & $15.84 \pm 8.77$ \\
\hline Zeolite & $20.61 \pm 11.12$ & $18.94 \pm 9.66$ & $16.76 \pm 8.47$ & $17.22 \pm 8.67$ \\
\hline Clay & $373.33 \pm 22.01$ & $357.36 \pm 20.79$ & $344.33 \pm 19.72$ & $349.79 \pm 18.09$ \\
\hline Carbon+Clay & $78.10 \pm 16.29$ & $72.11 \pm 15.57$ & $66.20 \pm 13.34$ & $68.74 \pm 14.04$ \\
\hline Carbon+Zeolite & $18.99 \pm 10.33$ & $17.58 \pm 9.38$ & $15.88 \pm 8.29$ & $16.45 \pm 8.53$ \\
\hline Clay+Zeolite & $129.72 \pm 31.82$ & $120.49 \pm 31.47$ & $110.95 \pm 30.92$ & $114.84 \pm 32.03$ \\
\hline Carbon+Clay+Zeolite & $16.54 \pm 9.20$ & $15.32 \pm 8.65$ & $* 14.02 \pm 7.67$ & $14.81 \pm 8.11$ \\
\hline
\end{tabular}

For discharged wastewaters, the maximum limit values for $\mathrm{Al}, \mathrm{Cd}, \mathrm{Cu}$ are 3,5 and $5 \mathrm{mg} \mathrm{L}^{-1}$, respectively (Filiz, 2007; Kalipci and Ceylan, 2017). The values met in the regulation were written with italics. Asterisk "*" symbol shows the highest removal value for the 6th hour of the treatment for related heavy metals.

\subsection{The experimental samples contained harmful heavy metals}

The $\mathrm{Al}, \mathrm{Cd}, \mathrm{Cu}, \mathrm{Ni}, \mathrm{Pb}$ and $\mathrm{Zn}$ contents of the samples before and after the treatment are given in Table 2 and Table 3. $\mathrm{Cd}, \mathrm{Cu}, \mathrm{Ni}, \mathrm{Pb}$, and $\mathrm{Zn}$ were detected in the samples, while $\mathrm{Cu}$ and $\mathrm{Zn}$ were the most abundant ones. Furthermore, a massive increase in the $\mathrm{Al}$ concentration of the samples was observed in the samples treated with zeolite (Table 2 and Table 3 ).

The high heavy metal content of the samples suggested that the wastewater generated in dye production cannot be directly discharged to the environment or reused without any treatment. Although wastewater treatment procedures bring additional costs to manufacturers, it is necessary to apply them thoroughly and in a controlled manner.

\subsection{The maximum removal was achieved at the 6th hour of the treatment}

We determined that the efficacy of the removal of heavy metals started to decrease after the 6 th hour of the treatment. The adsorption of heavy metals reached a saturation point at the 6th hour of the treatment $(p<0.05)$. The desorption started after the 6th hour, and therefore the concentrations of heavy metals started to re-increase in the samples (Table 1). In other words, adsorbents should be separated from wastewater after the 6th hour of the treatment as a good practice criterion.

\subsection{Clay-zeolite-activated carbon mixture provided the best heavy metal removal according to the mean values compared to other groups but differences between the groups are not statistically significant}

In this study, zeolite and clay were tested as alternative materials to activated carbon which is the most commonly used material in wastewater treatment, to develop a more costeffective way. According to the mean values, clay provided much worse results compared to activated carbon while zeolite and active carbon+zeolite treatments also provided nearly the same results with activated carbon treatment (Table 1). However, Chaari et al. (2008) found that clay can have better performance compared to activated carbon in terms of lead adsorption when it is activated with sulphuric acid. This difference is probably due to the lack of clay activation in our study. We also determined that active carbon+zeolite mixture provided better performance compared to active carbon only in 
Table 3

Temporal changes in the heavy metal contents of the samples after the treatment with adsorbents $(\mathrm{Pb}, \mathrm{Ni}$ and $\mathrm{Zn})$.

\begin{tabular}{|c|c|c|c|c|}
\hline \multicolumn{5}{|c|}{ Lead Concentration $\left(\mathrm{mg} \mathrm{L}^{-1}\right)($ mean $\pm \mathrm{SD})($ th Hour 32.28 \pm 5.75$)$} \\
\hline Time/Treatment & 2th Hour & 4ht Hour & 6th Hour & 8th Hour \\
\hline Carbon & $2.48 \pm 1.25$ & $2.23 \pm 1.26$ & $2.05 \pm 1.23$ & $2.19 \pm 1.29$ \\
\hline Zeolite & $2.70 \pm 1.88$ & $2.38 \pm 1.81$ & $2.17 \pm 1.72$ & $2.38 \pm 1.79$ \\
\hline Clay & $19.97 \pm 5.92$ & $17.63 \pm 5.01$ & $14.85 \pm 4.12$ & $16.13 \pm 4.73$ \\
\hline Carbon+Clay & $7.16 \pm 2.55$ & $6.12 \pm 2.52$ & $5.52 \pm 2.53$ & $5.76 \pm 2.48$ \\
\hline Carbon+Zeolite & $2.64 \pm 1.56$ & $2.43 \pm 1.44$ & $2.23 \pm 1.43$ & $2.39 \pm 1.47$ \\
\hline Clay+Zeolite & $11.95 \pm 4.20$ & $10.18 \pm 3.35$ & $8.87 \pm 2.79$ & $9.53 \pm 3.15$ \\
\hline Carbon+Clay+Zeolite & $2.06 \pm 1.32$ & $1.87 \pm 1.26$ & $* 1.68 \pm 1.17$ & $1.82 \pm 1.24$ \\
\hline \multicolumn{5}{|c|}{ Nickel Concentration $\left(\mathrm{mg} \mathrm{L}^{-1}\right)($ mean \pm SD) $(0$ th Hour $95.56 \pm 13.05)$} \\
\hline Time/Treatment & 2th Hour & 4th Hour & 6th Hour & 8th Hour \\
\hline Carbon & $3.66 \pm 1.21$ & $3.18 \pm 1.15$ & $2.98 \pm 1.15$ & $3.14 \pm 1.16$ \\
\hline Zeolite & $4.57 \pm 1.35$ & $4.04 \pm 1.30$ & $3.71 \pm 1.22$ & $3.92 \pm 1.18$ \\
\hline Clay & $47.54 \pm 3.19$ & $41.66 \pm 3.06$ & $36.04 \pm 3.40$ & $39.19 \pm 2.53$ \\
\hline Carbon+Clay & $16.41 \pm 5.37$ & $14.16 \pm 4.47$ & $12.18 \pm 4.16$ & $12.95 \pm 4.41$ \\
\hline Carbon+Zeolite & $3.91 \pm 1.38$ & $3.57 \pm 1.27$ & $3.26 \pm 1.22$ & $3.45 \pm 1.31$ \\
\hline Clay+Zeolite & $25.59 \pm 4.72$ & $22.12 \pm 4.02$ & $18.17 \pm 2.70$ & $19.80 \pm 2.85$ \\
\hline Carbon+Clay+Zeolite & $3.35 \pm 0.85$ & $3.06 \pm 0.85$ & $* 2.86 \pm 0.80$ & $3.01 \pm 0.79$ \\
\hline \multicolumn{5}{|c|}{ Zinc Concentration $\left(\mathrm{mg} \mathrm{L}^{-1}\right)($ mean \pm SD) $(0$ th Hour 398.71 \pm 40.59$)$} \\
\hline Time/Treatment & 2th Hour & 4th Hour & 6th Hour & 8th Hour \\
\hline Carbon & $12.44 \pm 3.18$ & $11.31 \pm 2.85$ & $10.06 \pm 2.20$ & $10.63 \pm 2.56$ \\
\hline Zeolite & $13.76 \pm 4.30$ & $13.31 \pm 4.24$ & $11.37 \pm 3.37$ & $12.38 \pm 3.83$ \\
\hline Clay & $153.34 \pm 39.73$ & $143.90 \pm 38.29$ & $133.31 \pm 36.70$ & $137.87 \pm 35.74$ \\
\hline Carbon+Clay & $43.68 \pm 16.22$ & $39.48 \pm 15.55$ & $34.65 \pm 14.01$ & $36.33 \pm 14.30$ \\
\hline Carbon+Zeolite & $13.01 \pm 3.77$ & $11.52 \pm 2.86$ & $10.44 \pm 2.35$ & $11.33 \pm 2.77$ \\
\hline Clay+Zeolite & $68.82 \pm 24.21$ & $61.47 \pm 21.92$ & $55.23 \pm 21.08$ & $60.49 \pm 22.26$ \\
\hline Carbon+Clay+Zeolite & $11.24 \pm 2.89$ & $9.89 \pm 2.28$ & $* 8.89 \pm 1.64$ & $9.77 \pm 2.24$ \\
\hline
\end{tabular}

For discharged wastewaters, The maximum limit values for $\mathrm{Al}, \mathrm{Cd}, \mathrm{Cu}$ are 3, 5 and $5 \mathrm{mg} \mathrm{L}^{-1}$, respectively (Filiz, 2007; Kalipci and Ceylan, 2017). The values met in the regulation were written with italics. Asterisk "*" symbol shows the highest removal value for the 6th hour of the treatment for related heavy metals.

terms of cadmium removal (Table 1).

Active carbon+clay+zeolite treatment was the most effective mixture for removing $\mathrm{Cd}, \mathrm{Cu}, \mathrm{Ni}, \mathrm{Pb}$, and $\mathrm{Zn}$ compared to other groups including activated carbon (Table 1). In other words, clay only improved the ability to remove heavy metals when it was combined with both zeolite and activated carbon because clay+carbon treatment and clay+zeolite treatment had lower treatment efficiencies compared to active carbon treatment and zeolite treatment, respectively. Mixtures can behave differently compared to their components, and our findings indicate a positive synergistic effect between clay, activated carbon, and zeolite in terms of the removal of heavy metals. Unfortunately, these findings were not statistically significant, probably due to high standard deviation values. We prepared 5 different samples with 5 different dyes for each of the seven treatment groups and calculated mean and standard deviation values for each group with them. This condition may lead to high standard deviations, and therefore experimental repetitions for each treatment group should be made with samples prepared by using the same dye in further studies.

Some other researchers also studied composite adsorbents such as silica+activated carbon, clay+activated carbon composites for removing heavy metals (Karnib et al., 2014;
Pawar et al., 2018). Karnib et al. (2014) showed that the silica+activated carbon (2:3) composite provided a slightly higher Ni removal rate compared to activated carbon, while activated carbon had a significantly higher $\mathrm{Ni}$ removal rate compared to silica. However, we found that activated carbon provided higher Ni removal compared to the zeolite+activated carbon (1:1) mixture; this difference may be as a result of the difference between silicated materials and the ratio of components.

\subsection{The addition of zeolite in the samples for heavy metal removal increased the concentration Al as a probable adverse effect of $\mathrm{HNO}_{3}$ using in the experimental procedure}

$\mathrm{Al}$ is one of the most abundant metals in all soils, and its levels range between $0.45 \%$ to $10 \%$ (Kabata-Pendias and Pendias, 2001). Al cannot be absorbed by plants from the soil as long as the $\mathrm{pH}$ of soil does not range between 4-4.5 (Matsumoto, 2000; Vardar et al., 2006). For the aquatic environment, the toxicity of $\mathrm{Al}$ is altered by the $\mathrm{pH}$ and physicochemical properties of water (Jaishankar et al., 2014). Al can causes growth problems in plants in acidic soil and disturbs the reproductive system, respiratory system, cardiovascular system, 
endocrine system, blood, and gill structure of aquatic animals. It also has well-established toxic effects on human bone marrow, skeletal muscles, heart, liver, and brain for excess concentrations (Nayak, 2002). In our study, Al concentration in the samples increased after zeolite or zeolite containing mixtures applied to the samples.

From this point of view, Al should be removed from the wastewater with an additional treatment step before discharge to avoid toxic concentrations of $\mathrm{Al}$ when zeolite is used for heavy metal removal However, this finding is controversial because other studies determined that zeolite only dissolved when the $\mathrm{pH}$ drop to below 2.0 and then $\mathrm{Al}$ concentration increase in the solution and even some researchers successfully removed Al by using zeolite (Wingenfelder et al., 2005; Abdullah, 2014). Although we found higher Al concentrations in the samples treated with zeolite or zeolite containing mixture, this condition is probably as a result of the addition of $\mathrm{HNO}_{3}$ during the experimental procedure. For further studies, the experimental procedure should be modified to eliminate this possibility. This condition may also be related to the content of the natural zeolite.

\section{Conclusion}

Our findings are promising for using clay, zeolite, and activated carbon in combination to obtain better heavy metal removal yield and to minimize wastewater treatment costs. Further studies should be designed for the experimental repetitions with low standard deviation values or conducted with a higher number of samples, and thus statistically significant results may be obtained. The molecular mechanisms under the synergistic interactions between clay, active carbon, and zeolite should be enlightened in terms of heavy metal removal from wastewater. We also found a significant threshold value for the

\section{References}

Abdullah, A. M. (2014). Aluminum pollution removal from water using a natural zeolite. Journal of Pollution Effects \& Control, 1-4.

Arora, S. (2014). Textile dyes: it's impact on environment and its treatment. Journal of Bioremediation \& Biodegredation, 5(3), 1.

Babel, S., \& Kurniawan, T. A. (2003). Low-cost adsorbents for heavy metals uptake from contaminated water: a review. Journal of Hazardous Materials, 97(1-3), 219-243.

Banat, I. M., Nigam, P., Singh, D., \& Marchant, R. (1996). Microbial decolorization of textile-dyecontaining effluents: a review. Bioresource Technology, 58(3), 217-227.

Bhardwaj, V., Kumar, P. \& Singhal, G. (2014). Toxicity of heavy metals pollutants in textile mills effluents. International Journal of Scientific and Engineering Research, 5(7), 2229-5518.

Bolisetty, S., Peydayesh, M. \& Mezzenga, R. (2019). Sustainable technologies for water purification from heavy metals: review and analysis. Chemical Society Reviews, 48(2), 463-487.

Chaari, I., Fakhfakh, E., Chakroun, S., Bouzid, J., Boujelben, N., Feki, M. \& Jamoussi, F. (2008). Lead removal from aqueous solutions by a Tunisian smectitic clay. Journal of Hazardous Materials, 156(1-3), $545-551$

Demir, E. (2008). Isıl işlemin bir bentonitin katyon değiştirme kapasitesi, adsorpsiyon, gözenekliliği, yüzey alanı ve yüzey asitliği gibi bazı fizikokimyasal özelliklerine etkisi, Doktora Tezi, (pp. 1-180) Ankara Üniversitesi, Fen Bilimleri Enstitüsü, Türkiye.

Dogan, I., Ozyigit, I. I., \& Demir, G. (2014). Influence of aluminum on mineral nutrient uptake and accumulation in Urtica pilulifera L.. Journal of Plant Nutrition, 37(3), 469-481.

Dogan, I., Ozyigit, I. I., Tombuloglu, G., Sakcali, M. S., \& Tombuloglu, H. (2016). Assessment of Cd-induced genotoxic damage in Urtica pilulifera L. using RAPD-PCR analysis. Biotechnology \& Biotechnological Equipment, 30(2), 284-291. duration of treatment, and this finding indicates that an optimum treatment duration exists and longer treatment is not better for every time.

\subsection{Limitations of the study}

Our sample number is limited, only 5 samples were included in the study for each material or mixture used in the treatment, and this low number of samples may be one of the limitations of the study. Another limitation of the study is that we prepared our samples in the laboratory to imitate textile factories' wastewaters. Our samples only contained dye residues, while the real textile industry's wastewaters contain other pollutants, and their contents are more complex. Therefore, our study may only reflect the properties of real wastewater noncomprehensively. Although synthetic zeolites provide better results according to the literature, we used natural zeolite. This condition probably negatively affected our results. In other words, further studies should be designed for synthetic zeolite+activated carbon+clay mixtures to obtain better results. Also, we did not test the active carbon+clay+zeolite mixture for different concentrations of dyes. However, its heavy metal removal performance can be negatively affected by increasing pollutant concentrations. Thus, its heavy metal removal capacity per unit mass of the pollutants cannot be determined in this way when it is tested for only one concentration of heavy metals.

Conflict of interest: The authors declare that they have no conflict of interests.

Informed consent: This manuscript did not involve human or animal participants; therefore informed consent was not collected.

Donlon, B., Razo-Flores, E., Luijten, M., Swarts, H., Lettinga, G., \& Field, J. (1997). Detoxification and partial mineralization of the azo dye mordant orange 1 in a continuous upflow anaerobic sludge-blanket reactor. Applied Microbiology and Biotechnology, 47(1), 83-90.

Filiz, E. (2007). Doğal kaynaklardan elde edilen adsorbanlarla sulardan ağır metal giderimi, Yüksek Lisans Tezi, (pp. 1-139) İstanbul Teknik Üniversitesi, Fen Bilimleri Enstitüsü, Türkiye.

Genchi, G., Carocci, A., Lauria, G., Sinicropi, M. S., \& Catalano, A. (2020). Nickel: Human health and environmental toxicology. International Journal of Environmental Research and Public Health, 17(3), 679.

Gu, Q., \& Lin, R. L. (2010). Heavy metals zinc, cadmium, and copper stimulate pulmonary sensory neurons via direct activation of TRPA1. Journal of Applied Physiology, 108(4), 891-897.

Gulen, J., Zorbay, F., \& Arslan, S. (2012). Zeolitler ve kullanım alanları. Karaelmas Fen ve Mühendislik Dergisi, 2(1), 63-68.

Halimoon, N., \& Yin, R. G. S. (2010). Removal of heavy metals from textile wastewater using zeolite. Environment Asia, 3(2010), 124-130.

Hocaoglu-Ozyigit, A., \& Genc, B. N. (2020). Cadmium in plants, humans and the environment. Frontiers in Life Sciences and Related Technologies, 1(1), 12-21.

Isci, S. (2002). Bentonit dispersiyonlarına organik ve inorganik katkıların adsorbsiyonunun reolojik özellikleri üzerine etkisi, Yüksek Lisans Tezi, (pp.1-61) İstanbul Teknik Üniversitesi, Fen Bilimleri Enstitüsü, Türkiye.

Jaishankar, M., Tseten, T., Anbalagan, N., Mathew, B. B., \& Beeregowda, K. N. (2014). Toxicity, mechanism and health effects of some heavy metals. Interdisciplinary Toxicology, 7(2), 60.

Jaroniec, M., \& Choma, J. (1986). Characterization of heterogeneity of activated carbons by utilizing the benzene adsorption data. Materials Chemistry and Physics, 15(6), 521-536.

Kabata-Pendias, A., Pendias, H. (2001). Trace elements in soils and plants. 
3rd ed., (pp. 1-432). CRC Press, Boca Raton New York, Washington, D.C.

Kalipci, E., \& Ceylan, Z. (2017). Konya ana tahliye kanalında ağır metal kirliliğinin izlenmesi. Dicle Üniversitesi Mühendislik Fakültesi Mühendislik Dergisi, 8(3), 649-658.

Kapdan, I. K., \& Kargi, F. (2000). Removal of textile dyestufes from wastewater by adsorptive biodegradation. Turkish Journal of Engineering and Environmental Sciences, 24(3), 161-170.

Karnib, M., Kabbani, A., Holail, H., \& Olama, Z. (2014). Heavy metals removal using activated carbon, silica and silica activated carbon composite. Energy Procedia, 50, 113-120.

Mathur, H. B., Agarwal, H. C., Johnson, S., \& Saikia, N. (2005). Analysis of pesticide residues in blood samples from villages of Punjab. Centre for Science and Environment, India, 1-15.

Matsumoto, H. (2000). Cell biology of aluminum toxicity and tolerance in higher plants, International Review of Cytology, 1-46.

Mercimek, H. (2007). Trametes versicolor'in tekstil boyalarının gideriminde kullanım olanakları, Yüksek Lisans Tezi, (pp. 1-74) Çukurova Üniversitesi, Fen Bilimleri Enstitüsü, Türkiye.

Nayak, P. (2002). Aluminum: impacts and disease. Environmental Research, 89(2), 101-115.

Ozyigit, I. I., Dogan, I., Igdelioglu, S., Filiz, E., Karadeniz, S., \& Uzunova, Z. (2016). Screening of damage induced by lead $(\mathrm{Pb})$ in rye (Secale cereale L.) a genetic and physiological approach. Biotechnology \& Biotechnological Equipment, 30(3), 489-496.

Ozyigit, I. I., Yalcin, B., Turan, S., Saracoglu, I. A., Karadeniz, S., Yalcin, I. E., \& Demir, G. (2018). Investigation of heavy metal level and mineral nutrient status in widely used medicinal plants' leaves in Turkey: Insights into health implications. Biological Trace Element Research, 182(2), 387-406.

Ozyigit, I. I., Kaval, A., Cakir, E. A., \& Vardar, F. (2019). DNA fingerprinting and assessment of some physiological changes in $\mathrm{Al}-$ induced Bryophyllum daigremontianum clones. Molecular Biology Reports, 46(3), 2703-2711.

Pagga, U., \& Brown, D. (1986). The degradation of dyestuffs: Part II Behaviour of dyestuffs in aerobic biodegradation tests. Chemosphere, 15(4), 479-491.

Pawar, R. R., Kim, M., Kim, J. G., Hong, S. M., Sawant, S. Y., \& Lee, S. M. (2018). Efficient removal of hazardous lead, cadmium, and arsenic from aqueous environment by iron oxide modified clay-activated carbon composite beads. Applied Clay Science, 162, 339-350.

Pohl, W. L. (2011). Economic geology: principles and practice. (pp. 1-678). John Wiley \& Sons.

Rahimzadeh, M. R., Rahimzadeh, M. R., Kazemi, S., \& Moghadamnia, A. A. (2017). Cadmium toxicity and treatment: An update. Caspian Journal of Internal Medicine, 8(3), 135.

Rashed, M. N. (2013). Adsorption technique for the removal of organic pollutants from water and wastewater. Organic Pollutants-Monitoring,
Risk and Treatment, 7, 167-194.

Santos, S. C., \& Boaventura, R. A. (2008). Adsorption modelling of textile dyes by sepiolite. Applied Clay Science, 42(1-2), 137-145.

Shevade, S., \& Ford, R. G. (2004). Use of synthetic zeolites for arsenate removal from pollutant water. Water Research, 38(14-15), 3197-3204.

Shrivastava, A. K. (2009). A review on copper pollution and its removal from water bodies by pollution control technologies. Indian Journal of Environmental Protection, 29(6), 552-560.

Suresh, G., Ramasamy, V., Sundarrajan, M., \& Paramasivam, K. (2015). Spatial and vertical distributions of heavy metals and their potential toxicity levels in various beach sediments from high-backgroundradiation area, Kerala, India. Marine Pollution Bulletin, 91(1), 389-400.

Sener, S. (2008). Use of solid wastes of the soda ash plant as an adsorbent for the removal of anionic dyes: Equilibrium and kinetic studies. Chemical Engineering Journal, 138(1-3), 207-214.

Talarposhti, A. M., Donnelly, T., \& Anderson, G. K. (2001). Colour removal from a simulated dye wastewater using a two-phase anaerobic packed bed reactor. Water Research, 35(2), 425-432.

Tchobanoglous, G., Burton, F. L., \& Stensel, H. D. (1991). Wastewater engineering. Management, 7, 1-4.

Toprakezer, F. (2009). Nanokompozit sentezinde kullanılacak na-bentonit kilinin saflaştırılması, Yüksek Lisans Tezi, (pp. 1-80) Çukurova Üniversitesi, Fen Bilimleri Enstitüsü, Türkiye.

Uddin, M. K. (2017). A review on the adsorption of heavy metals by clay minerals, with special focus on the past decade. Chemical Engineering Journal, 308, 438-462.

Uzal, N., Yilmaz, L., \& Yetis, U. (2005). İndigo boyama atıklarının ön arıtımı: kimyasal çöktürme ön filtrasyon süreçlerinin karşılaştırılması, 6. Ulusal Çevre Müh. Kongresi, 429-437.

Vardar, F., Arican, E., \& Gozukirmizi, N. (2006). Effects of aluminum on in vitro root growth and seed germination of tobacco (Nicotiana tabacum L.). Advances in Food Sciences, 28(2), 85-88.

Wingenfelder, U., Hansen, C., Furrer, G., \& Schulin, R. (2005). Removal of heavy metals from mine waters by natural zeolites. Environmental Science \& Technology, 39(12), 4606-4613.

Yalcin, I. E., Ozyigit, I. I., Dogan, I., Demir, G., \& Yarci, C. (2020). Using the Turkish red pine tree to monitor heavy metal pollution. Polish Journal of Environmental Studies, 29(5), 3881-3889.

Yasar, U., \& Ozyigit, I. I. (2009). Use of human hair as a potential biomonitor for zinc in the Pendik District Istanbul Turkey. Romanian Biotechnological Letters, 14(3), 4474-4481.

Yilmaz, N., Ozyigit, I. I., Demir, H. H., \& Yalcin, I. E. (2021). Assessment on phytoplankton composition and heavy metal pollution in a drinking water resource: Lake Terkos (Istanbul, Turkey), Desalination and Water Treatment, 225, 265-274.

Zhang, X., Yang, L., Li, Y., Li, H., Wang, W., \& Ye, B. (2012). Impacts of lead/zinc mining and smelting on the environment and human health in China. Environmental Monitoring and Assessment, 184(4), 2261-2273.

Cite as: Turksoy, R., Terzioglu, G., Yalcin, I. E., Turksoy Terzioglu, O., \& Demir, G. (2021). Removal of heavy metals from textile industry wastewater. Front Life Sci RT, 2(2), 44-50. 